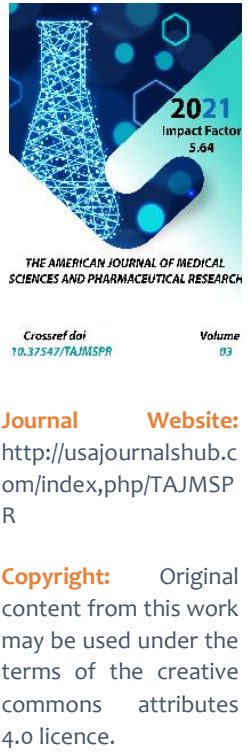

\title{
Description Of The Rules For The Evaluation Of External Signs In Physiognomics And Their Printouts, As Well As Research In The Field Of Pathophysiognomics
}

Polvanov Rasulbek Baxtiyarovich

Doctoral Student, Assistant Of The Department Of Nervous Diseases, Medical Psychology And Psychotherapy, Tashkent Medical Academy, Uzbekistan

Faqirov Alijon Zohidovich

Associate Professor Of The Department Of General And Pediatric Surgery Of The Tashkent Medical Academy, Candidate Of Medical Sciences, Excellent Worker Of Health Of The Republic Of Uzbekistan, Academician of The Academy Of Afrosiab Psychological Sciences, Uzbekistan

\section{ABSTRACT}

This article analyzes the rules and principles of assessment of external signs in physiognomy, the shape of the face, the appearance of its limbs, the identification of symptoms depending on the change, the description of the study.

\section{KEYWORDS}

"Physiognomics", "Pathophysiognomy", Psychosomatics, facial organs, eyes, eyelids and related diseases.

\section{INTRODUCTION}

Social economic reforms are the product of innovative activities aimed at creating new ideas and their implementation in large-scale and concrete junctions. Preparation of the future specialist for such activities is one of the most important socially important tasks. 
Bunda it is necessary to know the psychology of Man and to use this knowledge fully in communication with the individual. Accordingly, the study of the interdependence between the physiognomy of the individual and his / her consent is one of the pressing problems today.

\section{PURPOSE OF THE STUDY}

The relevance of physiognomy to medicine is the study of approaches based on the study of the characteristics of appearance and the relationship between human diseases.

Object of research юзнинг аъзолари кўз ва қовоқ билан боғлиқ ички ва ташқи соматик касалликлар ўртасидаги ўзаро боғлиқлик.

The term physiognomics is a phrase from two Greek words "physis" (nature) and "gnomikos" (related to knowledge and understanding). Therefore, physiognomy studies the knowledge of the person's facial features, appearance, the connection between his inner world, personality and Destiny. "Physiognomy "later became"physiognomy" in French and gave the meaning of" the image of man".

The roots of physiognomic Science go back to antiquity. This doctrine attracted all scientists, writers and philosophers. Such famous personalities as Pythagoras, Galen, Selsus, Cicero, Quintilian, small Plinians are interested in this science. For example, the selection of the famous Greek scientist Pythagoras shogards, who lived in the V-VII centuries, is based on their appearance. On their faces they practiced only when there was a tendency to certain Sciences. Ibn Sina, the Great Physician of the East, always checked the patient's face before making a diagnosis. But Aristotle has made great strides in knowing this science.

K.Tepperwain himself wrote in his book "the face - mirror: pathophysiognomics for everyone divides the rules of face reading into the following".

1) Noverbal data, for example, hysteria that spreads through the face of a person, the quality and level of changes in it, as well as the evaluation of data of an intuitive character;

2) Regular monitoring of specific symptoms, as well as ignoring their behavior;

3) Each self-productivity can be compared with others and the results of this observation can be evaluated objectively;

4) To draw correct conclusions from the results of observation and to use it for a more general diagnosis. At the same time, it is necessary to expand and deepen personal experience. After the analysis, it is necessary to once again go to the synthesis and confirm the conclusions made by observation (if it is worked out).

Another Authors A.E.Georgievna and D.A.Alexandrovna divides the rules of face reading into the following in the book of the great encyclopedia "face reading from facial mimics".

1-th rule. When checking someone else's face, do not look closely at the person. If he feels that you are studying, he will suspect that something is wrong and will start to get nervous. As a result, your analysis will remain one-sided.

Rule Number 2. Do not stand too close to the person. You will spoil his personal self-esteem, which will cause anxiety and cause a change in facial expression. This is in turn saba that the information obtained will turn out to be incorrect. An alternative distance should be at least 50 centimeters. But the person who interests you and the distance between you is not recommended to be more than a meter away: you can not read many signals of facial expressions, by staying away. 
Rule Number 3. Best of all it is worthwhile to study in a state of light in a normal situation where a person's face does not dazzle. In this case, all wrinkles and wrinkles on the skin will look natural. If the condition is directly exposed to sunlight, the analysis loses its accuracy.

Rule 4. Do not try to analyze the face of a Kayf or a drunk person. Mast facial emojis of a person in a state of intoxication change their character. In addition, in a state of intoxication, the face itself may blush and some signals may be vague.

Rule number 5. Do not study the face of a sleeping person. In the effect of sleep, all people change. The body condition and facial expressions of a sleeping person are separate areas of physiognomic research.

Rule number 6 . Do not try to read anything from a face that has burns or scars for some reason. This in turn hides different emotions. One can not guarantee the correctness of the information read from the face with burns or scars. Physiognomics is also a medical-related aspect, and there are several approaches based on the study of the properties of appearance and the relationship between human diseases.

External character evaluation prints:

1) All external manifestations of the disease, above all, can be the cause of the mental state; this is primarily due to the thinking and behavior of a person;

2) The presence of this or that sign can give evidence of the disease or predisposition to it;

3) If several signs indicate the presence of a particular disease, then it is possible that it did not really manifest its appearance;

4) The fact that any symptom of a disease or disease is the cause of a person's past life style means that in the future it is necessary to change this way of life. In this case, the probability of spontaneous disappearance of the symptom of the disease increases.

Dealing with pathophysiognomics requires a highly developed level of observation, good memory, intensive practice, obvious intelligence and the ability to combine the results of observation. To formulate and develop such a skill, it is necessary to adhere to the following rules.

Psychosomatics (Greek zosha - body) is a relatively new direction in medical psychology, which studies the effect of psychological factors on the appearance of a number of somatic diseases. There are several theories to explain their origin. According to one of them, it is stress that occurs as a result of long-term psychosomatic disorders and incurable psychological trauma, which leaves traces of tenderness on the face itself. According to another theory, in the emergence of psychosomatic disorders, the individual correlates with an internal conflict between intensiveness and anti-dependent motivations. The idea of a person's well-being, his close connection with his mental, emotional state, is considered one of the most important in modern medicine. The direction of Psychosomatics, which is developing today, is very widely used to determine the health of a person and correlate diseases with psychoogen factors. According to WHO, $45 \%$ of patients who turn to doctors, according to some researchers - 70\% fall into a group of Psychosomatic patients.

Of many researchers (R.Dalne, L.Burbo, K.Tepperveyn, L.Hei, L.Viilma, K.Stecher, D.Summarizing the data of Shapiro and others), there is a correlation between internal and external diseases. Proceeding from this, we can note that the main psychoogen factors are aggressiveness (a wrong look at what is 
happening) and emotions (a predominance of negative emotions).

Kurt Teppervayn said that his "face is a mirror of Health. In the book" pathophysiognomics for all", it is well illuminated to identify the signs of the disease, depending on the shape of the face, the appearance of its organs, changes. According to the author, this direction is called pathophysiognomics. Pathophysiognomics is the identification of diseases based on external signs on a person's face. If there is a symptom of a disease, it means that there is a predisposition to a particular disease, which can exert its influence throughout a different lifestyle. But if there are several such signs, although such signs do not manifest themselves, we can talk about the pathological process.

On the face of each person there will be information about his own pleasant past, what he likes and dislikes. At the same time, in the organs of the face, the sides of a person associated with diseases are manifested, reflecting them in color, appearance, condition.

In the process of giving them a conclusion, several of the most common reasons are listed, but, as a rule, in a person always one of them serves as the source of the disease.

For example, pain in the head often refers to spiritual dependence and is associated with increased external pressure, low self-esteem, a sense of guilt and excessive unreasonable compression. Some researchers describe the associated diseases of the eyes and bladder, which are members of the face, as follows.

Pale eyes-indicate a symptom of an infectious disease. Redness of the eyes-inflammation of the mucous membrane of the eyes, it is clear from colds. Yellow color of the eyeball - a symptom of liver dysfunction, hepatitis, yellow disease. The appearance of a bruise on the eye is a manifestation of hyperfunctioning of the thyroid gland. The appearance of red lines in the eye - indicates a symptom of venous congestion. Deeply located eyes-from boredom gives a comb. A purulent appearance of the eye is a sign of fever and excitement. The appearance of a bruise on the eye as a swelling is a sign of excessive weakness of the body. A person's cold stare is a symptom of intestinal diseases, Silla drying. The appearance of the eyes in a pearl color is a sign of tuberculosis or anemia. A lot of flushing of the eye-the presence of painful sensations. Too much reflection of the eye is a disease that is often associated with memory. Squint eyeshereditary-related diseases. Not crying is a symptom of vitamin A deficiency. Restless eye movements-the appearance of a symptom of fear, neurasthenia. Frequent puncture of the eye-vegetative - vascular dystonia, a strong manifestation of the symptom of hyperthyroidism. Low eye piercing is a symptom of hypothyroidism. Folded folds on the eyelids-the appearance of a symptom of high vegetative excitability. Insufficient twisting in the eyelids-the appearance of adinemia, severe fatigue.

Other authors L.P.Parshukova, V.M.Karlishev, Z.A.Shakurova in their books "Physiognomics" refers to diseases related to the eye, eyelid, and bring the following information. The eyelids reflect the state of the nervous system and, as a rule, they are not swollen and should be full. If the delicate skin of the eyelids has a high sensitivity, this leads to the conclusion that the nervous system is weak. A person with such caps can not cope with the difficulties of life. The presence of sunken eyelids at the top of the eyes is the consequence of the fact that such a person spends a lot of nerve power, and the need for sleep is depleted. Two layers on the upper eyelid of the eye - the appearance of a violation of the diaphragm (diaphragmatic hernia). The skin hangs on the eyelids - the 
presence of remgeld's syndrome. Swelling of the upper eyelid - a violation of the functioning of the heart. Hanging eyelids-the work of the heart with excessive force. The presence of a yellow-brown round protrusion in the eyelid of the upper part of the eye - a violation of the hormonal balance and the amount of cholesterin in the body. Sunkenness in the lower eyelids of the eyes - irritability, suffering of a person from fatigue. Swelling of the eyelid at the bottom of the eye - a violation of kidney activity, urine remains persistent. Pinkish edema of blue color on the lower eyelidviolation of the function of the bladder. Swelling of gray-green color in the eyelid at the bottom of the eye is a symptom of an excess of uric acid. Edema of a waxy color in the lower eyelid - the presence of diseases associated with the heart. The color of the bruise of the wreckage of the bladder is a sign of a lack of iron in the body. The batter part of the pumpkin has a dark color - the presence of neurasthenia. The fact that the lower eyelid of the eye has a brown hue is an indication of anemia. Pigmentation of the lower eyelid - the presence of hemorrhoids, this can also be internal. To determine the condition of the bladder in a person, it is possible to use the condition of the skin directly in the area under the eyelid. Approximately $1 \mathrm{~cm}$ below the eyelid indicates a small redness of the spot. "Halta" under the eyes indicates a violation of the work of the kidneys, a disease of the adrenal glands and glands of internal secretion. A large "haltah" hanging further down is a symptom of bowel disease.

Interrelation between body structure and psychological characteristics the body structure criteria (for example, neurological disorders, gland disorders or psychosomatic disorders) can affect behavior or behavior (for example, muscle development exercises) can affect physical conditions (for example, psychosomatic disorders). Such diseases can affect behavior in different ways. Severe mental or emotional disorders, such as cretinism, paralysis, and delirium tremens, can occur as a direct result of a decrease in the activity of the glands or a violation of brain activity. Evidence collected in other diseases, such as schizophrenia, is associated with a change in the structure of some of the corresponding body organs, but the causes of their occurrence are still unknown.

In place of the conclusion, it can be said that studies on appearance and behavior allow to explain the causes of several pathological conditions. And this, in turn, opens up the prospect for a causal omillarni study that identifies behavioral differences in the normal sequence.

\section{REFERENCES}

1. А.Е.Георгиевна, Д.О.Александровна. Чтение по жестам и лицам. Большая энциклопедия / - Москва: Эксмо, 2015. $240 \mathrm{C}$.

2. К.Теппервайн. Лицо - зеркало здоровья: патофизиогномика для всех. М.: АСТ: Астрель, 2006. - 223 с.

3. Паршукова Л.П., Карлышев В.М., Шакурова 3.А. Физиогномика / Серия «Высшее образование». - Ростов н/Д: Феникс, 2004. - 384 С.

4. Шапарь В.Б., Физиогномика / Серия «Библиотека пректикующего врача». Ростов н/Д: Феникс, 2015 г- 318 с.

5. В.В.Леонкин, Т.Клипина., Физиогномика для начинающих, или Читать человека, как книгу, Москва. 2008 150-190 с 